\title{
THE INFLUENCE OF PRICE, LOCATION, AND SERVICE ON FARMER'S DECISIONS TO SELL COCOA TO UD JAYA MAKMUR OF SIGI DISTRICT, CENTRAL SULAWESI PROVINCE OF INDONESIA
}

\author{
Badjamal Faigah A.* \\ Faculty of Economics, University of Alkhairat Palu, Indonesia
}

\author{
Abadiyah Ani Khuryatul \\ Faculty of Fisheries Science, University of Alkhairaat Palu, Indonesia \\ *E-mail: faigahbadjamal0165@gmail.com
}

\section{ABSTRACT}

The purpose of this study was to determine the effect of the price (X1), location (X2), and service (X3) on the farmer decision (Y) to sell cocoa to UD (Usaha Dagang or Indonesian trading company) Jaya Makmur in Sigi District. The population of this study was 330 people from the number of consumers coming to UD Jaya Makmur within three months. Since the number of population is too much, the authors only took 77 people as a respondent after drawing samples using Accident sampling. Data were processed using a statistical product and service solution program (SPSS 19.0), after conducting statistical tests using multiple linear regression analysis, the results showed that: 1) price, location, and service simultaneously had a significant effect on the decision to sell cocoa to UD Jaya Makmur in Sigi District; 2) Of the three factors, which factors relatively more dominant to influence the farmer decision to sell cocoa to UD Jaya Makmur.
\end{abstract}

\section{KEY WORDS}

Price factor, location factor, service factor, farmer's decision.

The cocoa bean originates from Central and South America. This plant was known in Indonesia around the 17th and 18th centuries under the Spanish people. Until today, it has been widely developing in various regions in Indonesia such as in North Sumatra, East Java, Irian Jaya, and special regions in central Sulawesi.

Cocoa beans are one of the export commodities, marketing of these commodities abroad is quite good and domestic demand continues to increase. The facts give a clue that the cocoa has a pretty good prospect if it is developed and its production increased.

Agricultural intensification is chosen to increase cocoa production. Meanhwile, the extensification of farming is an effort to increase production by expanding the area of cultivation. Diversification is the diversity of farming both vertical (production to marketing) and horizontal (a development between various commodities and regions). Rehabilitation is an activity to restore the critical productivity of agricultural resources. Many residents switch from the clove plant business to the cocoa business today. It is not only because the price is rising, but also the process of harvesting is not difficult. The cacao beans are easily picked due to its tree is relatively low compared to clove plants.

The marketing process of cocoa plants is relatively easy. The farmers directly go to buyers who have cocoa selling businesses, for example, the cocoa farmers in Sigi District sell their cocoa to UD Jaya Makmur, and the company sells it back to buyers who directly serve requests to be exported.

Field observations showed that the cocoa farmers in Sigi district and other regions tend to sell cocoa to UD Jaya Makmur because of various factors such as price, services, and location, which is easy to achieve so they do not need additional cost for transportation. If the purchase price is high, the benefits of the company will also high, therefore; the farmers choose to sell their cocoa to UD Jaya Makmur, because they do not need a cost for transportation. 
UD Jaya Makmur also automatically creates bargaining conditions between companies and farmers. As for services, average farmers do not like services with too long and difficult administration. Difficult services tend to make farmers switch to other places considered serve well and easy to reach.

The farmer consideration about the cost of transportation and cocoa maintenance from the risk of damage during the trip has become an opportunity for UD Jaya Makmur to improve the competitiveness of the company.

The question addressed from this phenomenon is: what attracts the farmers to sell cocoa to UD Jaya Makmur, whether it is because of price, service, or location.

Objectives of study:

- Price, location, and service had an influence on the farmer's decision to sell cocoa to UD Jaya Makmur in Sigi District;

- To find out that price had an influence on the farmer's decision to sell cocoa to UD Jaya Makmur in Sigi District;

- To find out that location had an influence on the farmer's decision to sell cocoa to UD Jaya Makmur in Sigi District;

- To find out those services had an influence on the farmer's decision to sell cocoa to UD Jaya Makmur in Sigi District.

\section{LITERATURE REVIEW}

Marketing is a function that identifies wants and needs. Measuring the size of the market will help to determine the best target market and the right location. The company must be able and endeavor to attract the interests of consumers in choosing products in the marketing scope, including among others, pricing activities, location, and services to sell.

Theoretically, the definition of marketing has been put forward by many economists. According to Stanton (2003), marketing is a process in which individuals and groups get what they need and want by creating and exchanging products and values with other individuals and groups. While according to Kotler (2017), marketing is a process that gives individuals and groups what they need and wants by creating and exchanging products and values with other individuals and groups. Nugroho $(2010 ; 6)$ defined marketing management as as a plan designed to influence the exchange, both limited, broad, or complex, of one party with another party.

Hence, it can be concluded that marketing is a systematic process of exchanges, limited to the buyer and the seller. It also can be described as an attempt that determines price, location, and service where consumers will get the deception to sell products.

Complicated decision-making processes often involve several decisions. It could be a choice between two or more options or decision always requires a choice between several different things. According to Nugroho $(2010 ; 2)$, consumer decision marketing is an integration process that combines knowledge to evaluate two or more alternative behaviors and choose one of them. The result of this integration process is a choice, presented cognitively as a desire to behave. A company must pay attention to the perception of the community to know the community's reason to sell products. The perception of the community to choose a company to sell products is called consumer behavior. Engel (1995) stated that consumer decisions are the actions of individuals who are directly involved in the business of obtaining, using, and deciding products and services, including the decisionmaking process that precedes and follows these actions.

Whereas (Swasta and Handoko; 2011) stated that consumer decision is a motivational process that underlies and leads to the decision-making in purchasing goods or services according to their current needs.

It can be concluded that the consumer's decision precedes the actions of the community to sell products. In this case, marketing management needs to know the consumer behavior, including the pattern of choosing a product. Hence, the company can more effectively develop pricing, promote, and distribute products.

Price is the value of a product imposed by the company on farmers to sell the product. 
According to (Swast and Handoko; 2011), price is the amount of money (plus a few products if possible) needed to get a combination of products and services. Whereas Ronald (2004) stated that price is product competitiveness, among others, determined by price competitiveness, and cost advantage. Hence, the price competitiveness can be achieved if the company seeks a cost advantage. The efficiency in the production process shows that the price advantage can be achieved through the economic scale that will reduce the price of per-unit products where the number of products is on a large scale. Price comes first (X1).

Location is a place to carry out sales strategies by a company. Also, it is one of the factors that influence the community to sell the cocoa to the company.

The service factor involves the procedures of the boss and employees of UD Jaya Makmur in serving farmers to sell the cocoa. Theoretically, the meaning of the service can be understood through the opinions of experts. According to Kotler (2007), service is the activities or benefits or satisfaction offered with sales. The service factor involves the procedures of the boss and employees of UD Jaya Makmur in serving the community. Service is a variable studied with friendliness and speed indicator.

Hypothesis:

$\mathrm{H} 1$ : Price, location, and service allegedly affected the farmer's decison to sell cocoa to UD Jaya Makmur; District;

$\mathrm{H} 2$ : Price allegedly affected the farmer's decision to sell cocoa to UD Jaya Makmur Sigi

H3: Location allegedly affected the farmer's decision to sell cocoa to UD Jaya Makmur Sigi District;

H4: Service allegedly affected the farmer's decision to sell cocoa to UD Jaya Makmur Sigi District.

\section{METHODS OF RESEARCH}

This study was associative research that aimed to determine the effect or the relationship between two or more variables. This research has the highest level compared to descriptive and comparative study because this research can build a theory that provides a function to explain, predict, and control a phenomenon (Sugiyono, 2010).

This research was conducted at UD Jaya Makmur, Sigi District, Central Sulawesi Province, Indonesia from May 2018 until July 2018. Data were collected by distributing questionnaires or structured questionnaires that had been prepared previously.

The population and sample of this study were all farmers, totalling 330 people, who decided to sell cocoa to UD Jaya Makmur. The 77 respondents were determined using the formulation of Taro Yamane (in Ridwan, 2005; 65).

Sampling was carried out using a random sampling technique, namely the way to take samples from members of the population using random methods without regarding strata in the population (Sugiyono, 2010). The steps to choose the sample of respondents are as follows:

- A farmer deciding to sell cocoa will be chosen according to a predetermined amount;

- Farmers who are interested in selling the cocoa at UD Jaya Makmur will be selected according to the amount determined by the company. The name of those selected will be written on a small piece of paper;

- Those pieces of paper were then rolled and put in a tube and shaken, then issued one by one;

- The rolled-paper coming out was recorded as a sample and returned in a tube, then shaken to get the next sample;

- If the previous name comes out, it is returned and shaken again until another name comes out as many as the number needed. It was repeated until fulfilled the number of samples.

In total, the responses of respondents were obtained through 77 questionnaires. All questionnaires were then returned to the researchers. Besides, interviews were also done to 8 people based on their respective fields of expertise named Arman, Sapri, Anto, Haris, 
Darman, Andi, Arifin, Nasar. They were interviewed to discuss things related to the objectives of the study to obtain information more efficiently.

This research variable will measure four variables studied: farmer's decision to sell cocoa $(Y)$ is the dependent variable, price $(X 1)$, location (X2) and service (X3) are independent variables.

The analytical method used was the classical assumption test, multiple linear regression analysis, and $\mathrm{F}$ hypothesis testing and t-hypothesis testing.

Validity test is a measuring tool used to get data. Valid means the instrument can be used to measure what should be measured (Sugiyono, 2010).

Instrument reliability means a reliable measurement result. Reliable instruments are needed to obtain data fitting the measurement objectives. The reliability test is performed using the Cronbach's alpha method.

Normality test aims to test whether the model in regression, dependent variable, independent variable, or both have normal distribution or not. A good regression model has a normal data distribution.

Based on Ghozali (2005: 105), heteroscedasticity test aims to test whether, in the regression, there is an inequality of variance from the residuals of one observation to another. Heteroscedasticity shows the spread of free variables. Random distribution shows a good regression model.

Multicollinearity test aims to test whether the regression model found a correlation between independent variables. The correlation between the independent variables should not occur if the regression model is good (Ghozali, 2005; 91). There are several criteria to determine the existence of multicollinearity:

- If the VIF value $>10$ or if the tolerance value $<1$, there will be multicollinearity in the regression model;

- If the VIF value $<10$ or if the tolerance value $>1$, there will be no multicollinearity in the regression model.

Regression analysis tools were used to determine the effect of price (X1), location (X2) and service (X3), on the farmer's decision (Y). Based on Hartono $(2011 ; 164)$, the regression equation of this study is:

$$
Y=a+b 1 X 1+b 2 X 2+b 3 X 3+e
$$

$F$ test is used to determine whether there is a joint influence between independent variables on the dependent variable. The t statistical test or partial test aims to find out how far the influence of individual independent variables in explaining bound variables. Ghozali (2005: 110) stated that t-test is used to test the regression coefficient partially from the independent variable with criteria:

- Alternative hypotheses are accepted if the significance value $<0.05$;

- Alternative hypotheses are accepted if the significance value> 0.05 .

\section{RESULTS AND DISCUSSION}

Table 1 shows that the significance value for each statement is $<0.05$, so it can be concluded that each statement is valid. Cronbach's alpha value for each statement> 0.6 , so it can be concluded that each statement is reliable.

The classical assumption test consists of a normality test, a heteroscedasticity test, a multicollinearity test, and an autocorrelation test. The classical assumption test consists of a normality test, a heterokedasticity test, a multicollinearity test, and an autocorrelation test.

Figure 1 shows that the P-P normal graph of regression standardized residual illustrates the spread of data around the diagonal line and its distribution follows the diagonal line of the graph, so the regression model has fulfilled the normality assumption.

Figure 2 shows the scatterplot graphs displayed for heteroscedasticity test. The points spread randomly and no clear patterns formed. Also, the points spread below and above 0 
on $\mathrm{Y}$ growth, identifying no heteroscedasticity in the model regression, so the regression model is feasible to predict.

Table 1 - Validity and reliability test

\begin{tabular}{|c|c|c|c|c|c|}
\hline Variable & Question & Sig & Status & Cronbach's Alpha & Status \\
\hline & X1.1 & 0.000 & Valid & & Reliable \\
Price (X1) & X1.2 & 0.000 & Valid & \multirow{2}{*}{0.827} & Reliable \\
& X1.3 & 0.000 & Valid & & Reliable \\
& X1.4 & 0.000 & Valid & & Reliable \\
\hline & X2.1 & 0.000 & Valid & & Reliable \\
Location (X2) & X2.2 & 0.000 & Valid & \multirow{2}{*}{0.711} & Reliable \\
& X2.3 & 0.000 & Valid & & Reliable \\
\hline & X2 4 & 0.000 & Valid & & Reliable \\
& X3.1 & 0.000 & Valid & & Reliable \\
Service (X3) & X3.2 & 0.000 & Valid & \multirow{2}{*}{0.717} & Reliable \\
& X3.3 & 0.000 & Valid & & Reliable \\
\hline \multirow{2}{*}{ Decision (Y) } & X3.4 & 0.000 & Valid & & Reliable \\
& Y1.1 & 0.000 & Valid & & Reliable \\
& Y1.2 & 0.000 & Valid & \multirow{2}{*}{0.758} & Reliable \\
\hline
\end{tabular}

Source: The result of data processing using SPSS 19, 2018.

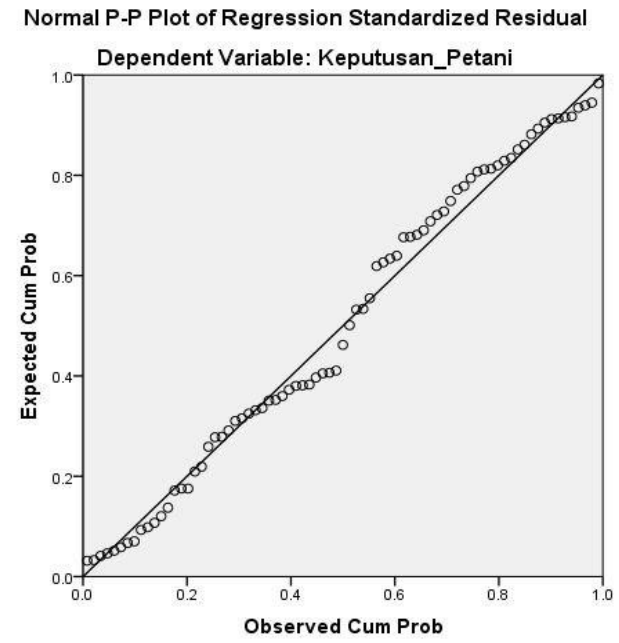

Figure 1 - Classical Assumption Test for Normality (Source: The result of data processing using SPSS 19, 2018)

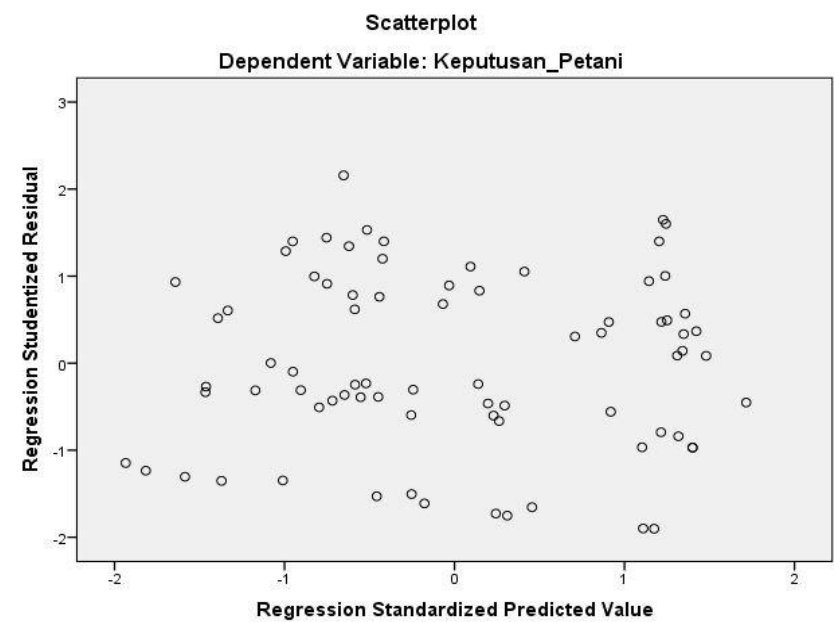

Figure 2 - Heteroscedasticity classical assumption test (Source: The result of data processing using SPSS 19, 2018) 
Table 2 - Multicollinearity Test

\begin{tabular}{|c|c|c|}
\hline \multirow{2}{*}{ Model } & \multicolumn{2}{|c|}{ Collinearity Statistics } \\
\cline { 2 - 3 } & Tolerance & VIF \\
\hline Price $(\mathrm{X} 1)$ & .986 & 1,092 \\
Location $(\mathrm{X} 2)$ & .954 & 1,014 \\
Service $\left(\mathrm{X}_{3}\right)$ & .947 & 1,048 \\
\hline
\end{tabular}

Source: The result of data processing using SPSS 19, 2018.

Table 2 shows the output of SPSS, and there are no symptoms of multicollinearity if the VIF value $<10$. The results produce VIF for multiple regressions below 10 , so it can be concluded that there are no symptoms of multicollinearity in the regression model.

Table 3 - Multiple linear regression analysis

\begin{tabular}{|c|c|}
\hline \multirow{2}{*}{ Model } & Unstandarized Coefficients \\
\cline { 2 - 2 } & $B$ \\
\hline (Constant) & 58,921 \\
\hline Price & .204 \\
Location & .089 \\
Service & .172 \\
\hline
\end{tabular}

Source: The result of data processing using SPSS 19, 2018.

Table 3 shows the multiple linear regression equation:

$$
Y=58.921+0.204 X 1+0,089 X 2+0172 X 3+11.32926
$$

The regression equation $Y=58.921+0.204 X 1+0.089 X 2+0.172 X 3+11,32926$ illustrates that the price (X1), location (X2), and service (X3) can be stated if one independent variable changes by one and the other constant, the change in the purchase decision $(Y)$ is equal to the coefficient $(b)$ of the independent variable value. The constant of 58.921 gives the sense that if the price $\left(X_{1}\right)$, location $(X 1)$, and service $(X 3)$ simultaneously do not change or equal to zero, the score of the farmer's decision $(Y)$ is 58,921 units.

If the value of $b 1$, which is the regression coefficient of the price $\left(X_{1}\right)$, is 0.204 , it had a positive influence on the dependent variable $(Y)$. It could be understood that if the price variable $(X 1)$ increases in units, the farmer's decision $(Y)$ will also increase by 0.204 units assuming other variables are fixed or constant. If if the value of $b 2$, which is the regression coefficient of location (X2), is $\mathbf{0 . 0 8 9}$, it had a negative influence on the dependent variable $(Y)$. It could be understood that if the location (X2) variable decreases by one unit, the farmer's decision $(Y)$ will decrease by -0.089 units assuming other variables are fixed or constant. If the value of $b 3$, which is the regression coefficient of price (X3), is 0.172 , it had a positive effect on the dependent variable (Y). It could be understood if the service (X3) variable increases the units, the farmer's decision $(\mathrm{Y})$ will also increase by 0.172 units assuming other variables are fixed or constant.

Table 4 - Coefficient of Determination

\begin{tabular}{|c|c|c|c|}
\hline Model & $\mathrm{R}$ & R Square & Adjusted R Square \\
\hline 1 & .573 & .329 & .289 \\
\hline
\end{tabular}

Source: The result of data processing using SPSS 19, 2018.

Table 4 shows that the $(R)$ value is equal to 0.573 , meaning it has a strong relationship. The adjusted $R$ Square value is 0.289 or $28.9 \%$, meaning the influence of price $\left(X_{1}\right)$, location (X2) and service (X3) on the farmer's decision is $28.9 \%$ and the rest $71.1 \%$ is influenced by other variables.

Table 5 shows the $\mathrm{F}$ test aims to simultaneously test all independent variables that will influence the farmer's decision jointly. Meanwhile, t-test aims to partially test the effect of independent variables on dependent variables. 
Table 5 - Hypothesis testing

\begin{tabular}{|c|c|c|c|c|}
\hline \multirow{2}{*}{ Model } & \multicolumn{2}{|c|}{ F test } & \multicolumn{2}{|c|}{ T test } \\
\cline { 4 - 5 } & $\mathrm{F}$ & Sig & $\mathrm{t}$ & Sig \\
\hline Constant & \multirow{3}{*}{5,776} & \multirow{2}{*}{0.000} & 2,456 & .018 \\
\hline Price & \multirow{2}{*}{5,955} & .000 \\
\hline Location & & 1,480 & .045 \\
\hline Service & & .522 & .046 \\
\hline
\end{tabular}

Source: The result of data processing using SPSS 19, 2018.

The results of the analysis using SPSS 19 obtained Simultaneous Test ( $F$ test) with a significant level of $p$-value $=0.000<0.05$, it can be concluded that $\mathrm{H}_{0}$ is rejected and $\mathrm{H}_{\mathrm{a}}$ is accepted, meaning that price (X1), location (X2), and service (X3) had a simultaneous and significant effect on farmer's decisions $(Y)$. Table 5 shows that the significance of $p$-value $=$ $0.000<0.05$, so it can be concluded that $\mathrm{Ha}$ is accepted and $\mathrm{H} 0$ is rejected or price (X1) had a significant effect on the farmer's decision $(Y)$. The results of t-test revealed that the location $\left(X_{2}\right)$ had a significance of $p$-value $=0.145>0.05$, so it can be concluded that $H_{a}$ is rejected and $H_{0}$ is accepted. Location (X2) had no significant effect on farmers' decisions (Y). The results of the t-test revealed that the service $(X 3)$ had a significance of $p$-value $=0.046$ > 0.05 , so it can be concluded that $\mathrm{H}_{a}$ is accepted and $\mathrm{H} 0$ is rejected. Service (X3) had a significant effect on farmer's decisions $(Y)$.

Price is the amount of money, charged for a product or service and the amount of value exchanged to get benefits from products and services. The result showed that the price had a significant effect on the farmer's decision to sell cocoa to UD Jaya Makmur. The higher the price of cocoa, the more satisfied the farmers receive their rewards, so the companies try their best to motivate farmers to sell their agricultural products. These research results are supported by the study conducted by Luci Angraini (2015) entitled factors affecting farmer's preferences in selling their agricultural products, a case study at UD Manik Galih Kota Parigi, stating that the price had a positive and significant influence on the farmer's decision to sell their agricultural products.

In this study, a location is a place for companies to conduct transaction activities, selling and buying, and also getting services. The results of this study indicated that location had a significant effect on farmer's decisions because the distance of UD Jaya Makmur is not so far from their houses and cocoa garden. This research is different from the previous study conducted by Asmidar (2014) entitled the influence of price, promotion, location, and product quality on farmer's decision to sell agricultural products to UD Jaya Tani in Poso District. Specifically, the location had a positive and significant influence on farmer's decisions.

Service is a concern and attention to the needs offered so the needs can be achieved. The farmer's decision to sell agricultural production is influenced by the service of UD Jaya Makmur. The results of this study are supported by Musna's (2012) research entitled analyzing factors that influence the farmer to sell coffee bean to UD Bintang Soraya in Palu City. The result showed that service had a positive and significant influence on farmers' decisions to sell coffee.

\section{CONCLUSION}

Price, location, and service simultaneously had an influence on the farmer's decision to sell cocoa to UD Jaya Makmur. Price partially had an influence on the farmer's decision to sell cocoa to UD Jaya Makmur. Location partially had an influence on farmer's decision to sell cocoato to UD Jaya Makmur. The location of UD Jaya Makmur did not affect the farmer's decisions. Service had an influence on the farmers' decision to sell cocoa to UD Jaya Makmur in Sigi District. Good service greatly influences farmer's decisions.

Several suggestions are as follows:

- Because the price and service had a positive and significant influence on farmer's decisions, the management of UD Jaya Makmur should pay attention to the price and service; 
- The results of the study can be used to develop marketing management knowledge, specifically, several variables like price, location, and service that influence farmer's decisions;

- This study was only limited to the effect of price, location and service on farmers' decisions. However, other variables also affect the decisions of farmers, so the future study is expected to discuss other variables that have not been discussed yet.

\section{REFERENCES}

1. Basu, S. \& Hani, H. 2011. Manajemen Pemasaran-Analisis Perilaku konsumen. Yogyakarta: BPFE.

2. Engel, J.F., Blackwell, R.D. \& Miniard, P.W. (1995). Perilaku Konsumen. Tangerang: Binarupa Aksara Publisher.

3. Ghozali, I. 2005.Aplikasi Analisis Multivariate dengan SPSS. Semarang: Badan Penerbit UNDIP.

4. Hartono, J. 2011.Metodologi Penelitian Bisnis: Salah Kaprah and PengalamanPengalaman. BPFE. Yogyakarta.

5. Kotler, P. 2007. Manajemen Pemasaran edisi kedua. Jakarta: UD. Indeks.

6. Nangoi, R. 2004. Pemberdayaan di Era Ekonomi Pengetahuan. Jakarta: UD. Grasindo.

7. Nugroho J.S. 2010. Perilaku Konsumen: Fourth Edition, Revised Version. Jakarta: Kencana. Ridwan. 2005. Skala Pengukuran Variabel-Variabel Penelitian. Bandung: Alfabeta.

8. Stanton, W.J. 2003. Manajemen Pemasaran. Translated by S. Sundaru. Jakarta: Erlangga.

9. Sugiyono. 2010. Metode penelitian bisnis. Bandung: CV. Alfabeta. 